\title{
MODEL AIDA SEBAGAI STRATEGI PEMASARAN BAGI NASABAH MENGAMBANG PERBANKAN SYARIAH (SURVEI MASYARAKAT DI KOTA BEKASI)
}

\author{
Silviana1) \\ Purnama Putra2) \\ 1)BTN Syariah Kantor Cabang Bekasi \\ 2)Universitas Islam 45 \\ e-mail: silviana.vie@gmail.com
}

\begin{abstract}
As a country with moslem as the majority, Indonesia turns out to be the market of sharia Banking Industry. Yet, ironically, Sharia Banking only has market segmentation of 4,86\% from the total banking service industry. This research focuses on the mapping of floating customers of sharia banking and marketing strategies done to interest future customers to be loyal customers using the model of Attention, Interest, Desire, and Action (AIDA). Bekasi is chosen as the research site since it is one of the capital city backbone for human resources and industries. The method used is a mixed method with the approach of concurrent embedded. The result shows that $54 \%$ sample of the people in Bekasi are floating customers of sharia banks. Sharia banks around Bekasi have also implemented AIDA models to turn the floating into loyal customers. The recommendation posed by the floating customers is that sharia banks are supposed to enhance the service given to them in terms of socialization and promotion.
\end{abstract}

Keywords: AIDA, floating customer, marketing strategy

\begin{abstract}
ABSTRAK
Indonesia sebagai negara yang mayoritas berpenduduk muslim menjadi pangsa pasar industri perbankan syariah. Hal yang menjadi ironi bahwa Perbankan syariah hanya mempunyai segmen pasar 4,86\% dari total industri layanan jasa perbankan. Riset ini berfokus pada pemetaan Nasabah Mengambang Perbankan Syariah dan strategi promosi yang dilakukan Bank Syariah untuk menarik calon nasabah menjadi nasabah loyalis menggunakan model Attention, Interest, Desire dan Action (AIDA). Bekasi dipilih menjadi lokasi penelitian ini dikarenakan sebagai daerah penyangga ibukota baik dari aspek sumberdaya manusia maupun industrinya. Metode yang digunakan dalam adalah metode kombinasi dengan pendekatan concurrent embedded. Hasil dalam riset ini bahwa $54 \%$ masyarakat kota Bekasi merupakan nasabah mengambang perbankan syariah. Perbankan syariah sudah menerapkan metode AIDA dalam strategi pemasarannya untuk menarik nasabah mengambang menjadi loyalis. Rekomendasi yang diberikan oleh nasabah mengambang yang mendapatkan porsi terbesar dengan melakukan peningkatan pelayanan sebagai perwujudan sosialisasi dan promosi kepada nasabah mengambang.
\end{abstract}

Kata kunci: AIDA, nasabah menkambang, strategi pemasaran 
Potensi pertumbuhan perbankan syariah di Indonesia sangat besar. Salah satu faktor pendukungnya adalah mayoritas penduduk Indonesia yang beragama Islam. Sistem perbankan syariah diatur dalam UU No.10 tahun 1998, yang merupakan undang-undang pengganti UU No.7 tahun 1992. Sejak diberlakukannya undang-undang tersebut, perkembangan perbankan syariah di Indonesia cukup pesat. Apalagi sejak diberlakukannya UU No.21 tahun 2008 tentang Perbankan Syariah yang terbit tanggal 16 Juli 2008 yang membuat pengembangan industri perbankan syariah nasional semakin memiliki landasan hukum yang memadai dan mendorong pertumbuhannya lebih cepat lagi. Dukungan terhadap pengembangan perbankan syariah juga diperlihatkan dengan adanya "dual banking system", yaitu pemberian izin kepada Bank Umum Konvensional untuk membuka kantor cabang Unit Usaha Syariah (UUS) atau konversi sebuah Bank Umum Konvensional menjadi Bank Umum Syariah (BUS).

Berdasarkan data yang didapat dari Bank Indonesia sampai dengan bulan Januari 2017, industri perbankan syariah telah mempunyai jaringan sebanyak 13 Bank Umum Syariah (BUS), 21 Unit Usaha Syariah (UUS), dan 166 BPRS, dengan total jaringan kantor mencapai 2.555 kantor BUS maupun UUS yang tersebar di hampir seluruh penjuru nusantara. (Otoritas Jasa Keuangan, 2017).

Tingginya jumlah penduduk umat Islam di Indonesia merupakan peluang yang sangat besar bagi Bank Syariah dalam meraih nasabah. Namun demikian, ada beberapa faktor yang harus diperhatikan oleh Bank Syariah agar mampu menarik minat nasabah. (Mairanda \& Putra, 2015). Meskipun Indonesia adalah negara dengan populasi umat muslim terbesar di dunia, yang jumlah penduduknya mencapai 230 juta jiwa pada 2012 (Biro Pusat Statistik, 2015), market share perbankan syariah di Indonesia hingga Juli 2016 hanya mencapai 4,86\%. Posisi ini naik jika dibandingkan dengan tahun lalu diperiode yang sama yaitu 4,46\%. Deputi Komisioner Pengawas Perbankan I OJK Mulya E. Siregar menyatakan bahwa: "Kondisi perekonomian nasional yang terus membaik sehingga telah berdampak pada pangsa pasar perbankan syariah, ditengah pelambatan ekonomi dunia Indonesia masih menunjukkan angka-angka yang positif sebagaimana yang terjadi di Perbankan Syariah". (Fuad, 2016).

Terdapat tiga segmen pasar perbankan syariah yaitu segmen syariah loyalist, segmen floating mass, dan segmen conventional loyalist. (Karim Business Consulting, 2005) Dari ketiga tipe segmen pasar tersebut, jumlah segmen yang terbanyak adalah nasabah mengambang / floating mass yang mencapai $80 \%$. Kenaikan jumlah nasabah yang tejadi di bank syariah ternyata bukan hanya disebabkan bertambah besarnya pangsa pasar segmen loyalis syariah, namun juga disebabkan bertambah banyaknya segmen floating mass yang menjadi nasabah perbankan syariah. Segmen ini menjadi nasabah bank syariah tanpa meninggalkan bank konvensional. Strategi promosi yang leih efektif diperlukan dalam mencapai market share perbankan syariah yang besar dengan menetapkan sasaran pada floating mass.

Pemasaran Bank Syariah bukan hal yang dianggap sepele dan para pengelola bank juga tidak tinggal diam. Tentu sudah banyak hal yang dilakukan untuk mendobrak kinerja pemasaran sebuah bank syariah. Pemasaran umumnya langsung pada takaran produk tertentu yang dimiliki oleh Bank Syariah. Berbeda, misalnya sebuah bank ada yang mempunyai layanan kredit perumahan syariah, deposito syariah dan lain sebagainya. Produk atau layanan bank syariah di Indonesia umumnya telah dilaksanakan melalui berbagai program atau media,mulai dari pamflet, iklan, buletin gratis hingga mengikuti pameran perbankan syariah. Intinya, program dan strategi pemasaran dilakukan pada sebuah aktivitas untuk menawarkan produk yang spesifik dari sebuah bank. (Wadhan, 2011) 
Strategi pemasaran yang efektif menurut Kotler dan Armstrong (2008) akan bisa terlihat apabila pesan yang disampaikan mampu mendapatkan perhatian/attention, menghantarkan kepada minat / interest sehingga menimbulkan hasrat untuk membeli/desire dan diakhiri dengan keputusan untuk membeli/action. Kerangka kerja pemasaran tersebut dikenal dengan Model AIDA (Lestari, 2016).

Perilaku segmen floating mass yang menjadi nasabah bank syariah tanpa meninggalkan bank konvensional ini menarik untuk dikaji lebih lanjut dari aspek strategi pemasaran serta dikarenakan potensi market share perbankan syariah di Indonesia sebenarnya sangatlah besar. Penelitian ini membatasi lingkupnya di Kota Bekasi yang merupakan salah satu daerah penyangga ibukota dengan jumlah penduduk di Bekasi tahun 2012 mencapai 2,5 juta jiwa (Putra, 2016).Penelitian ini berusaha mengetahui potensi floating mass serta strategi promosi yang dilakukan Bank Syariah di Kota Bekasi untuk menarik calon nasabah menjadi nasabah loyalis menggunakan model AIDA.

Metode penelitian yang digunakan dalam penelitian ini adalah metode kombinasi. Model metode kombinasi yang digunakan dalam penelitian ini adalah concurrent embedded (campuran tidak berimbang). Model metode concurrent embedded adalah metode penelitian yang menggabungkan antara metode penelitian kualitatif dan kuantitatif dengan cara mencampur kedua metode tersebut secara tidak seimbang, dimana metode penelitian kualitatif sebagai metode primer dan metode penelitian kuantitatif diskriptif sebagai metode sekunder (Creswell, 2010). Sampel diambil dengan metode purposive sampling (Sugiyono, 2013) dikarenakan peneliti harus melakukan pemetaan kategori nasabah di Bank Umum/Konvensional maupun Bank Syariah. Responden yang diambil datanya menggunakan kuisioner sebesar 100 orang dengan perincian wilayah 4 kecamatan yang berada disekitar Universitas Islam 45 Bekasi yaitu Mustika Jaya, Rawalumbu, Bekasi Timur dan Bekasi Selatan. Data primer dikumpulkan juga diperoleh langsung dari wawancara dan observasi peneliti dengan Head Funding Officer, staf marketing funding PT. Bank Muamalat Indonesia Cabang Bekasi Timur dan staff Karim BusinessConsulting yang berkaitan dengan strategi pemasaran dan variabel-variabel yang mempengaruhi segmentasi pangsa pasar masyarakat khususnya nasabah floating mass agar menjadi nasabah loyalis syariah.Data sekunder diperoleh peneliti dari PT. Bank Muamalat Indonesia Cabang Bekasi Timur mengenai jumlah nasabah dan total DPK serta studi pustaka terkait fokus penelitian. Data yang didapat berupa hasil wawancara dari pihak Bank Syariah, hasil kuisioner dari responden serta wawancara dengan staf Karim Business Consulting dilakukan triangulasi atas ketiga data tersebut untuk disajikan dalam tabel sederhana, kemudian diambil kesimpulan.

\section{HASIL DAN PEMBAHASAN Karakter Nasabah}

Head Funding Officer, Harmini, pada BMI cabang Kalimas Bekasi Timur, menjelaskan bahwa ada ada dua kriteria utama nasabah yang mereka layani (Harmini, 2013) yaitu: (1) Rasional Market, yaitu nasabah yang sangat berorientasi kepada pemberian bagi hasil atau bunga yang tinggi. Apabila ada bank yang dapat memberikan bagi hasil di bank syariah atau bunga pada bank konvensional yang lebih tinggi, maka ia akan menempatkan dananya pada bank tersebut, dan apabila bank tersebut memberikan hasil yang rendah maka ia akan pindah ke bank yang lain. (2) Emotional Market, merupakan nasabah yang loyalis karena terkait dengan emosi yang mungkin disebabkan pada pemahamannya tentang akidah, yaitu salah satunya pengetahuan bahwa bunga bank konvensional adalah haram dan bank syariah adalah halal. Nasabah yang paham tentang agama 
dan melakukan transaksi di bank syariah basanya karena nasabah tersebut menginginkan transaski yang full atau murni syariah, contohnya nasabah yang loyalis terhadap BMI biasanya memiliki alasan atau anggapan karena BMI merupakan satu-satunya bank syariah di Indonesia yang tidak memiliki unit atau tidak menginduk di bank konvensional, sehingga merupakan satu-satunya bank yang full dan murni syariah (Rosita, 2013). Loyalitas nasabah bisa dilihat dalam kurun waktu kurang lebih 1 tahun dari mutasi rekeningnya sejak dia mulai membuka rekening, apakah nasabah tersebut terus melakukan transaksinya ataukah dia akan berpindah-pindah ke bank lain. Nasabah yang loyalis biasanya tidak akan mementingkan dari aspek materi, tetapi lebih kepada kenyamanan yang telah ia rasakan sehingga membuatnya terus melanjutkan untuk menggunakan bank tersebut (Helmy, 2013).

Floating Mass menurut Helmy (Deputy Director Karim Consulting Indonesia, 2013) adalah nasabah yang lebih mengedepankan kepada aspek benefit, tidak hanya dari segi materi tetapi juga dalam melakukan transaksi. Jadi mereka tidak hanya melihat kepada aspek syariah atau tidak syariah, tapi lebih memikirkan kemudahan dalam bertransaksi, misalnya fasilitas seperti pelayananinternet banking, e-banking, dan lain-lain. Nasabah mengambang bisa muncul di Indonesia disebabkan oleh faktor rasional karena masalah keuangan, bisa karena kelebihan ataupun kekurangan uang, dan mereka akan mencari institusi yang dapat membantu menyelesaikan masalah keuangannya yang dapat lebih memberikan kemudahkan, lebih menjanjikan dan lebih efisien, misalnya dalam pemberian tingkat imbal hasil, administrasi, dan lain-lain.

Indikator nasabah mengambang berdasarkan penelitian yang telah dilakukan oleh Karim Consulting Indonesia, (Helmy, 2013) beberapa orang muslim yang merupakan nasabah mengambang banyak yang meragukan dan tidak menganggap bahwa bunga bank itu adalah haram, karena menurut mereka yang haram itu bukanlah bunga tetapi riba. Nasabah mengambang juga merupakan nasabah yang lebih mempertimbangkan aspek benefit dalam bertransaksi, mencari bank konvensional atau bank syariah yang dapat memberikan keuntungan yang lebih besar bagi mereka. Rata-rata nasabah mengambang adalah orang-orang terpelajar yang biasanya memiliki hobi membaca buku, berita, dan mencari informasi karena floating mass market lebih bersifat selalu membanding-bandingkan dari sisi servis dan benefitnya.

Tipe nasabah yang paling banyak di Indonesia adalah nasabah floating mass. Tidak hanya masyarakat muslim yang tertarik dengan bank syariah, akan tetapi fenomena yang terjadi banyak juga masyarakat non muslim yang tertarik dengan bank syariah, karena menurut mereka selama bank syariah juga dapat memberikan aksesyang lebih mudah, kantor dan pelayanan yang baik, mereka akan tertarik untuk memilih bank syariah. Bila masih ada masyarakat non muslim yang masih beranggapan bahwa bank syariah hanya untuk umat Islam, hal itu lebih disebabkan kepada masalah sosialisasi yang belum sampai kepada mereka. Jika informasinya bisa sampai kepada mereka, maka mereka juga bisa tertarik, karena ketika dari sisi keuntungan, produk dan sistem antara bank syariah dan bank konvensional sama, maka yang menjadi penilaian mereka adalah dari sisi pelayanannya. Pada akhirnya menjadi tidak relevan apabila bagian marketing hanya membicarakan masalah halal dan haram. Marketing di bank konvensional biasanya lebih aktif daripada bank syariah, karena mereka bisa mempunyai inisiatif sendiri unuk menggaet nasabah tanpa harus ada dorongan dari kepala cabang, karena mungkin dorongan untuk kerja berprestasi dibank konvensional lebih menjanjikan, dan dari sisi fasilitas yang ada mungkin masih belum setara dengan bank konvensional. Kemudian dari sisitraning SDM bank syariah juga dirasakan masih kurang.Kegiatan training di bank syariah biasanya lebih kepada produk, sementara trainingmotivasi dan emosionalnya masih kurang. Kemungkinan yang lainnya juga bisa disebabkan karena banyak SDM bank syariah yang diambil dari bank konvensional, sehingga mereka kebingungan untuk mencari pangsa pasar lain selain yang 
sudah digarap oleh bank konvensional. Ketika menggarap pasar baru, kemungkinkan marketing bank syariah memiliki terlalu banyak pertimbangan, sehingga action yang dilakukannya belum maksimal (Helmy, 2013).

Tabel 1. Potensi Masyarakat Bekasi Menggunakan Jasa Perbankan.

\begin{tabular}{ccc}
\hline Jenis Bank & Jumlah Responden & Persentase \\
\hline $\begin{array}{c}\text { Bank Konvensional (Loyalis } \\
\text { Konvensional) }\end{array}$ & 28 orang & $28 \%$ \\
$\begin{array}{c}\text { Bank Syariah (Loyalis Syariah) } \\
\text { Bank Konvensional dan } \\
\text { Bank Syariah (Nasabah } \\
\begin{array}{c}\text { Mengambang atau Floating } \\
\text { Mass) }\end{array}\end{array}$ & 18 orang & $18 \%$ \\
\hline Jumlah & 54 orang & $54 \%$ \\
\hline
\end{tabular}

Sumber : Hasil kuesioner

Berdasarkan Tabel 1 terlihat bahwa dari 100 responden yang diteliti, masyarakat Bekasi yang menggunakan jasa bank konvensional adalah 28 orang (28\%), menggunakan bank syariah 18 orang $(18 \%)$, dan yang menggunakan jasa keduanya bank konvensional dan bank syariah berjumlah 54 orang (54\%). Hal tersebut berarti mayoritasmasyarakat Bekasi adalah nasabah mengambang/ floating mass yaitu nasabah yang menggunakan jasa bank konvensional dan bank syariah.

Sedangkan yang paling sedikit adalah nasabah loyalis syariah yaitu masyarakat yang menggunakan jasa bank syariah saja dan loyalis konvensional yaitu nasabah yang hanya menggunakan jasa bank konvensional.

\section{Strategi Promosi}

Menurut Helmy (Deputy Director Karim Consulting Indonesia, 2013), sebagian besar nasabah floating mass tidak mau mendengarkan promosi dari jika hanya membicarakan masalah halal dan haramnya saja, tetapi pendekatan yang bisa dilakukan adalah dengan cara menawarkan kepada mereka tentang benefit atau keuntungan yang bisa mereka dapatkan apabila bertransaksi di bank syariah.Ada dua hal yang dapat dilakukan oleh bank syariah untuk menarik nasabah floating mass yaitu: (1) Bank syariah harus tetap menjaga syariah compliance. (2) Bank syariah harus tetap mempertimbangkan kemudahan dan kenyamanan dalam bertransaksi.

Dalam penelitian ini diperoleh hasil bahwa rata-rata nasabah mengambang rata-rata nasabah mengambang menyimpan dananya lebih banyak di bank konvensional daripada di bank syariah. Alasannya adalah karena lebih mudah dalam bertransaksi, cabang bank konvensional ada dimana-mana, kemudahan dalam melakukansms banking, rata-rata supplier dan rekanan kerja mereka juga banyak yang menggunakan bank konvensional, sehingga mereka lebih mengedepankan aspek kemudahannya dalam bertransaksi. Bila dipecah-pecah, pasar floating terdiri dari nasabah individual maupun korporasi yang menginginkan layanan perbankan biasa serta nasabah kakap yang tentunya membutuhkan layanan lebih bersifat privasi (Syibly, 2008) 
Strategi yang dilakukan BMI untuk menarik nasabah floating mass adalah dengan memberikan pemahaman tentang syariah Islam khususnya kepada yang muslim, contohnya tentang ayat-ayat di Al-Qur'an yang melarang riba, bahwa bunga bank konvensional termasuk kedalam riba yang diharamkan, karena tidak semua muslim memahami hal tersebut. Nasabah yang mengambang baiasanya pengetahuan agama mereka masih awam, Dari ketidakpahaman itulah akhirnya mereka belum loyal terhadap bank syariah sehingga sangat diperlukan sosialisasi kepada mereka. Untuk pendekatan kepada nasabah mengambang tersebut memang perlu usaha yang cukup keras dalam meyakinkan mereka dan harus bisa menyentuh hatinya, tapi juga tetap harus bisa memberikan kontribusi yang baik bagi mereka dengan memberikan bagi hasil yang kompetitif. Begitupula untuk nasabahnon muslim yang juga termasuk kedalam rasional market untuk bisa memberikan pelayanan dan servis yang baik karena mereka tentunya lebih menekankan kepada servis dan bagi hasil. Peran marketing sangatlah diperlukan untuk melakukan peranan penting tersebut. Marketing harus pintar dan cekatan dalam memberikan edukasi, sosialisasi, dan promosi kepada masyarakat, tidak hanya sekedar memperkenalkan produk, tapi juga harus bisa memperkenalkan secara lebih dalam. Salah satu contohnya adalah dengan berusaha untuk bisa menggandeng perusahaannya dengan menawarkan kerjasama, misalnya dalam bentuk payroll gaji agar dapat mempertahankan nasabah tersebut. (Rosita, 2013)

Dalam penelitian ini, analisis strategi promosi untuk menarik nasabah floating mass ke loyalis adalah dengan menggunakan Model analisis AIDA berdasarkan hasil kuesioner yang telah disebarkan oleh peneliti, yaitu:

1. Attention (Perhatian)

Berikut ini beberapa komponen dalam kuesioner yang dapat dijadikan ukuran untuk dapat menarik perhatian masyarakat, yaitu:

Tabel 2. Pemahaman Masyarakat Mengenai Perbedaan Bank Syariah dan Bank Konvensional.

\begin{tabular}{|c|c|c|c|c|}
\hline \multirow[b]{2}{*}{ Perbedaan } & \multicolumn{3}{|c|}{ Pernyataan Responden } & \multirow[b]{2}{*}{ Jumlah } \\
\hline & Mengetahui & Ragu-ragu & $\begin{array}{c}\text { Tidak } \\
\text { Mengetahui }\end{array}$ & \\
\hline $\begin{array}{l}\text { Bank Syariah } \\
\text { dan Bank } \\
\text { Konvensional }\end{array}$ & $\begin{array}{c}62 \text { orang } \\
(62 \%)\end{array}$ & $\begin{array}{c}14 \text { orang } \\
(14 \%)\end{array}$ & $\begin{array}{c}24 \text { orang } \\
(24 \%)\end{array}$ & $\begin{array}{c}100 \text { orang } \\
(100 \%)\end{array}$ \\
\hline $\begin{array}{l}\text { Bunga dan } \\
\text { Bagi Hasil }\end{array}$ & $\begin{array}{c}64 \text { orang } \\
(64 \%)\end{array}$ & $\begin{array}{c}16 \text { orang } \\
(16 \%)\end{array}$ & $\begin{array}{c}20 \text { orang } \\
(20 \%)\end{array}$ & $\begin{array}{c}100 \text { orang } \\
(100 \%)\end{array}$ \\
\hline
\end{tabular}

Sumber : hasil Kuisioner

Berdasarkan Tabel 2, ditunjukkan bahwa pemahaman masyarakat mengenai perbedaan bank syariah dan bank konvensional yaitu 62 orang (62\%) mengetahui, 14 orang (14\%) ragu-ragu, dan 24 orang (24\%) tidak mengetahui. Pemahaman mengenai bagi hasil dan bunga yaitu 64 orang (64\%) mengetahui, 16 orang (16\%) ragu-ragu, dan 20 orang (20\%) tidak mengetahui. Berdasarkan hasil tersebut, dapat disimpulkan bahwa masih ada masyarakat yang belum mengetahui perbedaan secara detail mengenai mekanisme perbedaan antara bank syariah dan bank konvensional. Maka dari itu, diperlukan adanya sosialisasi yang lebih mendalam kepada masyarakat.

Attention merupakan cara untuk menarik perhatian dari calon customer (Kotler \& Armstrong, 2008). Perhatian nasabah terhadap perbankan syariah sepertinya dirasa masih kurang karena 
banyak masyarakat yang belum memahami perbedaan bank syariah dan bank konvensional secara mendasar. Maka dari itu beberapa cara yang dapat diambil untuk menarik perhatian masyarakat contohnya adalah dengan mengadakan sosialisasi dan promosi tentang perbedaaan bagi hasil dan bunga pada bank konvensional agar masyarakat tidak beranggapan bahwa bank syariah dan bank konvensional sama saja.

Promosi yang dilakukan oleh BMI Cabang Bekasi Timur yaitu diantaranya adalah penyebaran brosur, pameran seperti membuka stan atau open table dan pemberian gimik atau souvenir. Promosi secara langsung seperti dari radio, tv, internet, dan media cetak tidak pernah dilakukan oleh cabang, karena hal tersebut merupakan wewenang kantor pusat. Cabang hanya memberikan sosialisasi kepada masyarakat. BMI Cabang Bekasi Timur biasanya melakukan open table sosialisasi ke KBIH, pengajian, ke masjid, dan lain-lain. Strategi funding hanya untuk menetapkan pasar mana yang ingin digarap seperti sekolah-sekolah, rumah sakit, perusahaan, industri, pedagang kecil, kaki lima, dan lain-lain. Pasar di luar bekasi seperti Jakarta juga didatangi oleh BMI Cabang Bekasi Timur, karena diarea Jakarta memiliki perputaran uang yang lebih banyak, biasanya nasabah tersebut adalah nasabah corporate (Rosita, 2013).

Strategi promosi produk funding yang dilakukan oleh BMI Cabang Kalimas Bekasi Timur yaitu, (1) Canvasing, (2) Presentasi ke yayasan, sekolah, dan perusahaan, (3) Inisiasi Gimmick pada produk tertentu yang sesuai dengan marketnya, (4) Inisiasi pembukaan Booth di pameran-pameran yang diadakan oleh instansi atau mall yang sesuai dengan target market BMI, (5) Mobile Branch sebagai entry point ke pasar tradisional atau pasar induk. (Harmini, 2013)

Promosi dari Bank Syariah sebenarnya sangatlah penting dan perlu ditingkatkan untuk dapat menarik perhatian masyarakat agar dapat mengenal Bank Syariah.

2. Interest (Menarik Minat)

Peneliti berusaha memetakan alasan masyarakat berminat untuk menjadi Nasabah di Bank Syariah dengan menggunakan indikator ketertarikan (Sari, Sumarwan, \& Hosen, 2015).

Tabel 3. Alasan Tertarik menjadi Nasabah Bank Syariah.

\begin{tabular}{cc}
\hline Alasan & Jumlah Responden \\
\hline Bagi Hasil yang besar & 16 \\
Lokasi & 10 \\
Pelayanan dan Kemudahan & 12 \\
Promosi dan Iklan & 17 \\
Produk dan Bebas Riba & 22 \\
Biaya Rendah & 8 \\
Alasan Lain & 15 \\
\hline Total & 100 \\
\hline
\end{tabular}

Sumber: Hasil Kuesioner

Berdasarkan Tabel 3 diketahui bahwa alasan ketertarikan menjadi nasabah yang paling kuat dikarenakan Produk dan Bebas Riba pada Bank Syariah. Di sisi lain Bank Syariah masih mempunyai biaya yang tinggi disebabkan karena skala usahan.

Keungggulan yang dimiliki oleh bank syariah adalah bagi hasil, sehingga Bank Syariah harus dapat menarik minat masyarakat dengan memberikan bagi hasil yang kompetitif dan dengan penjelasan akad yang lebih jelas dan rasional, agar masyarakat bisa mengerti mekanisme dan 
keunggulan bagi hasil yang sesungguhnya. Sebenarnya bagi hasil merupakan sistem yang halal dan lebih menguntungkan daripada sistem bunga, tetapi masih banyak masyarakat yang belum paham akan hal itu. (Harmini, 2013).

Mayoritas Penduduk Bekasi adalah muslim maka sebenarnya bank syariah telah mempunyai satu kelebihan yang istimewa yang tidak dimiliki oleh bank konvensional, sehingga untuk memaksimalkan kelebihan itu, maka bank syariah harus dapat membidik semua pangsa pasar yang ada di Indonesia, cara utamanya adalah dengan memperluas kegiatan promosi, sosialisasi, dan edukasi terhadap masyarakat.

\section{Desire (Keinginan/Kebutuhan)}

Strategi Promosi Bank Syariah harus mampu menggerakkan orang untuk memiliki atau menikmati produknya. Kebutuhan/keinginan calon nasabah untuk memiliki, memakai atau melakukan sesuatu harus dibangkitkan. (Kasali, 2005).

Tabel 4. Keinginan Masyarakat Terhadap Jasa Perbankan dengan Bunga/bagi Hasil Yang Tinggi.

\begin{tabular}{cc}
\hline Bank & Responden \\
\hline Bank Konvensional & 54 \\
Bank Syariah & 14 \\
Bank Syariah dan Konvensional & 32 \\
\hline Total & 100 \\
\hline
\end{tabular}

Sumber: Hasil Kuesioner

Apabila masyarakat dihadapkan untuk memilih menabung dibank syariah atau menabung di bank yang dapat memberikan bunga yang lebih tinggi, banyak masyarakat yang memilih menabung di bank syariah yaitu 54 orang karena kebanyakan masyarakat sebenarnya lebih menyukai sistem yang lebih syar'i dan halal sesuai agama. Namun, ada juga yang memilih bank konvensional dan memilih kedua-duanya, alasannya adalah karena mereka tetap membutuhkan transaksi di bank konvensional, karena fasilitas yang diberikan oleh bank syariah dirasa masih kurang bila dibandingkan bank konvensional. Seperti misalnya fasilitas mesin ATM, kantor cabang, dan aksesakses lainya seperti internet banking, merchant dan debit di pusat-pusat perbelanjaan dan berbagai fitur lainnya yang belum lengkap seperti yang telah dimiliki bank konvensional. Bank Syariah seharusnya dapat memahami kondisi pasar tersebut, sehingga lebih inovatif dalam memenuhi keinginan dan kebutuhan masyarakat agar masyarakat bisa mendapatkan kenyaman dalam bertransaksi dengan menggunakan Bank Syariah.

Tabel 5. Keinginan Untuk Membuat Rekening di Bank Syariah.

\begin{tabular}{cc}
\hline Sikap & Responden \\
\hline Ingin & 68 \\
Ragu-ragu & 22 \\
Tidak & 10 \\
\hline Total & 100 \\
\hline
\end{tabular}

Sumber: Hasil Kuesioner 
Banyak respon masyarakat Bekasi yang ingin membuka rekening di Bank Syariah yaitu 68 orang tetapi yang masih mereka harapkan adalah fasilitas dan kenyamanan yang lebih baik. Bank Syariah diharapkan menambah fasilitas yang lebih baik lagi untuk memenuhi kebutuhan nasabah tersebut, contohnya seperti memperbanyak lagi mesin-mesin ATM di tempat-tempat umum dan memperbanyak kantor cabang agar bisa dijangkau dengan mudah oleh nasabah.

Tabel 6. Kebutuhan Transaksi pada Jasa Perbankanberdasarkan Kepemilikan Rekening.

\begin{tabular}{ccccc}
\hline \multirow{2}{*}{ Jenis Bank } & \multicolumn{3}{c}{ Jumlah Rekening yang dimiliki } & \multirow{2}{*}{ Jumlah } \\
\cline { 2 - 4 } & Hanya 1 & $>1$ & Tidak Punya & \\
\hline Bank Syariah & 58 & 14 & 28 & 100 \\
Bank & 36 & 46 & 18 & 100 \\
Konvensional & 36 & & & \\
\hline Sumber: Hasil Kuesioner & & &
\end{tabular}

Tabel 6 memberikan informasi bahwa responden banyak yang membutuhkan jasa perbankan untuk transaksi keungannya baik di bank syariah maupun bank konvensional. Bahkan ada yang memiiki rekening lebih dari satu pada bank syariah maupun bank konvensional. Alasan mereka adalah untuk aspek kemudahan dalam bertransaksi dengan rekan kerja, akses kedekatan bank dengan rumah, dan aspek kenyamanan yang dapat diberikan oleh bank.

Bank Syariah harus bisa lebih optimal dalam memberikan fasilitas yang bisa mencakup dan memenuhi segala aspek yang dibutuhkan oleh masyarakat. Contohnya memberikan kemudahan dalam bertransaksi dengan memberikan fasilitas internet banking, prosedur dan persyaratan yang lebih mudah, biaya administrasi yang rendah, proses transfer dan penarikan yang lebih gampang dan cepat, dan segala hal yang dapat memberikan kenyamanan kepada nasabahnya.

Tabel 7. Kebutuhan Untuk Media Penyimpanan Dana Floating Mass

\begin{tabular}{lc}
\hline \multicolumn{1}{c}{ Penyimpanan Dana } & Responden \\
\hline Lebih Banyak di Bank Syariah & 18 \\
Lebih Banyak di Bank Konvensional & 28 \\
Seimbang & 8 \\
\hline Jumlah & 54
\end{tabular}

Sumber: Hasil Kuesioner

Nasabah floating mass pada sampel peneitian ini sebanyak 54 orang porsi yang lebih banyak menyimpan dananya pada bank konvensional yaitu 28 orang karena mereka menyatakan bahwa pelayanan dibank konvensional lebih mudah dan cepat, akses bank konvensional lebih mudah dan lebih banyak ada dimana-mana, relasi rekan kerja mereka lebih banyak yang menggunakan bank konvensional karena prosesnya dinilai lebih cepat. Sebenarnya bank syariah dapat melakukan hal yang sama bahkan lebih baik daripada bank konvensional, hanya saja sosialisasi yang belum sampai kepada masyarakat dan juga ketersediaan beberapa fasilitas yang mungkin masih kurang. Bank syariah dituntut agar dapat lebih baik dengan bisa memberikan kemudahan dan kenyamanan kepada masyarakat agar bisa bersaing dan menjadi lebih unggul daripada bank konvensional. 


\section{Action (Tindakan)}

Upaya terakhir sebagai perwujudan dari keberhasilan strategi pemasaran menggunakan model AIDA adalah dengan melakukan keputusan untuk memiliki, menggunakan produk Bank Syariah.

Tabel 8. Kemauan Floating Mass Menjadi Loyalis Perbankan Syariah.

\begin{tabular}{ccccc}
\hline Jenis Bank & \multicolumn{3}{c}{ Tingkat Kemauan } & Jumlah \\
\cline { 2 - 4 } & Mau & Ragu-ragu & Tidak mau & \\
\cline { 2 - 4 } Bank Syariah & 38 & 10 & 6 & 54 \\
\hline Sumber: & & &
\end{tabular}

Sumber : Hasil Kuesioner

Langkah yang terakhir untuk menggaet nasabah mengambang adalah bagaimana caranya agar dapat meyakinkan dan membuat nasabah tersebut bisa mengambil keputusan untuk memilih dan menggunakan produk yang ditawarkan. Berdasarkan Tabel 8, banyak pernyataan masyarakat yang mau menjadi nasabah loyalis pada bank syariah yaitu 38 orang. Hal ini memberi tanda bahwa di antara Nasabah Mengambang terdapat Nasabah Emosional. Adapun yang masih meragukan untuk menjadi loyalis Bank Syariah sebanyak 10 orang bahkan yang tidak mau untuk menjadi loyalis sebanyak 6 orang. Hal tersebut dikarenakan berbagai alasan dari mereka. Salah satunya karena Bank Syariah belum terkenal seperti bank konvensional dan berbagai alasan lainnya.Bank Syariah harus bisa lebih peka terhadap masukan-masukan dan penilaian dari masyarakat terhadap Bank Syariah agar bisa mengetahui kemauan dan keinginan masyarakat untuk menjadi nasabah loyalisnya sehingga bisa semakin mendorong kemajuan Perbankan Syariah.

Penelitian ini menambahkan rekomendasi yang berupa harapan diberikan oleh Nasabah mengambang (Floating Mass) Masyarakat Bekasi agar mereka bisa secara total beralih ke Perbankan Syariah diukur menggunakan indikator yang diberikan oleh Sari, et al (2015).

Tabel 9. Harapan Nasabah Mengambang Terhadap Perbankan Syariah.

\begin{tabular}{lc}
\hline Harapan & Responden \\
\hline Hadiah dan Undian & 22 \\
Fasilitas & 10 \\
Sosialisasi dan Promosi & 15 \\
Pelayanan/service & 24 \\
Variasi Produk & 12 \\
SDM & 7 \\
Lainya & 10 \\
\hline Total & 100 \\
\hline
\end{tabular}

Sumber: Hasil Kuesioner

Harapan-harapan Nasabah mengambang untuk mau menjadi nasabah loyalis BMI adalah adanya beberapa peningkatan yang harus dilakukan oleh Bank Syariah, diantaranya yang paling utama yaitu pelayanan/service yang lebih memuaskan, kemudian hadiah dan undian yang lebih besar atau menguntungkan, sosialisasi dan promosi yang lebih gencar (Suhendi, 2008), variasi produk yang lebih menarik, fasilitas yang lebih bagus dan tersebar seperti fasilitas mesin ATM agar memudahkan nasabahnya, pemekaran kantor cabang hingga ke pelosok daerah agar mudah 
dijangkau oleh nasabah, memberikan biaya administrasi dan angsuran pembiayaan yang lebih rendah, memberikan kemudahan dalam persyaratan dan prosedur-prosedur yang ada, memperluas akses dan fitur-fitur yang lebih canggih serta memperluas kerjasama dengan pusat-pusat perbelanjaan yang sering dikunjungi oleh nasabah agar semakin mempermudah akses dan transaksi.

Persepsi masyarakat yang masih banyak belum mengenal dan memahami sistem diperbankan syariah akan sangat mempengaruhi perkembangan bank syariah. Permasalahan tersebut menyangkut masalah sosialisasi karena ada persepsi masyarakat yang belum tentu sama dengan realita di lapangan. Persepsi di masyarakat bahwa bank syariah tidak terkenal, kantor jaringannya tidak begitu banyak, dan banyak juga masyarakat yang belum mengetahui bahwa mesin ATM bank konvensional juga bisa digunakan untuk ATM bank syariah, serta mereka juga banyak yang belum mengetahui bahwa kantor cabang bank konvensional juga bisa memberikan layanan transaksi bank syariah sangat mempengaruhi perkembangan bank syariah di Indonesia. Kebanyakan asumsi masyarakat hanya terfokus pada logo yang ada didepan bank saja apakah syariah atau bukan. Permasalahan sosialisasi sangat penting untuk segera diselesaikan. Masalah yang lainnya juga adalah masalah SDM bank syariah. SDM dibank syariah masih banyak yang belum cukup kompetensinya karena terkadang SDM yang diambil adalah dari bank konvensional. Terkadang proses seleksinya juga bukan lebih kepada aspek syariahnya. Bila mengambil dari fresh graduate, biasanya lebih melihat kepada latar belakang universitas dan hasil psikotesnya, bukan kepada jurusannya apakah sesuai dengan bidangnya di perbankan syariah atau ekonomi syariah. Akhirnya implikasi dilapangan, adalah banyak nasabahnya yang sudah bersemangat untuk bersyariah, tetapi karyawannya masih memakai pemikiran konvensional, sehingga akan membuat nasabah kecewa dan tidak mau bertransaksi di bank syariah. (Helmy, 2013).

Tantangan yang juga harus diselesaikan agar mendapatkan Loyalis Bank Syariah adalah beberapa respon masyarakat yang menilai bahwa bank konvensional terlihat selalu lebih mudah. Dari sisi jaringan bank konvensional memang selalu lebih mudah karena bank konvensional banyak dan ada dimana-mana. Dengan adanya UU Perbankan syariah, bank syariah juga diminta untuk memperbesar asetnya, terutama Unit Usaha Syariah (UUS). Karena tren yang terjadi sekarang Bank Umum Syariah (BUS) semakin meningkat karena UUS diminta untuk menyapih menjadi BUS yaitu maksimum 15 tahun sejak dikeluarkannya UU Perbankan Syariah No. 21 tahun 2008 yaitu tahun 2023 atau apabila asetnya sudah mencapai 50\% dari aset induk, maka UUS harus melepaskan diri dari induk syariahnya untuk menjadi BUS, bila tidak maka ia harus tutup. Untuk dapat melepaskan diri, maka UUS harus melakukan ekspansi, memperbesar volume pangsa pasarnya, contohnya dengan membuat produk yang lebih variatif, kompetitif dan marketingnya harus semakin gencar, serta akses dalam transaksinya juga semakin dipermudah.

\section{PENUTUP}

Nasabah Mengambang (floating mass) merupakan nasabah yang menggunakan perbankan konvensional dan perbankan syariah, karena nasabah floating mass merupakan nasabah yang bersifat selalu membandingkan atau memilih bank yang dapat memberikan keuntungan yang lebih besar, kemudahan dan kenyamanan yang lebih baik untuknya. Dari hasil riset ini, potensi nasabah floating mass di Kota Bekasi mencapai angka yang cukup banyak yaitu mencapai $54 \%$. Model Analisis AIDA digunakan untuk melihat keefektifan strategi pemasaran yang cukup efektif untuk dapat menarik nasabah floating mass menjadi nasabah loyalis, Menurut model ini, memberikan pelayanan optimal merupakan sosialisasi sekaligus promosi untuk menarik perhatian, mendapatkan 
dan mendorong minat konsumen, membangkitkan keinginan, dan menghasilkan tindakan atau keputusan pembelian.

Penelitian mengalami keterbatasan terkait data-data nasabah floating mass dikarenakan alasan Prudential Banking sehingga belum bisa melakukan pengukuran berapa besar Nasabah Mengambang yang berpindah menjadi loyalis di perbankan syariah. Disisi lain perbankan syariah dituntut untuk meningkatkan kinerja pemasarannya dengan dibuktikan meningkatnya aset, jumlah Dana Pihak Ketiga agar mampu bersaing dengan Bank Konvensional dalam memberikan pelayanan terbaik baik nasabahnya.

\section{REFERENSI}

Biro Pusat Statistik. (2015). Biro Pusat Statistik. Retrieved from www.bps.go.id.

Creswell, J. W. (2010). Research Design: Pendekatan Kualitatif, Kuantitatif dan Mixed. Yogyakarta: Pustaka Pelajar.

Fuad, H. (2016, September 27). ekbis.sindonews.com. Retrieved 2016, from ekbis.sindonews.com: www.ekbis.sindonews.com/read/1142707/178/market-share-bank-syariah-terus-meningkat1142707140.

Harmini, S. (2013, November 12). Head Funding Officer BMI Cabang Bekasi Timur. (Silviana, Interviewer).

Helmy, M. Y. (2013, Desember 23). Deputy Director Karim Consulting Indonesia. (Silviana, Interviewer).

Karim Business Consulting. (2005). Islamic Banking Consumer Behaviour in Indonesia: A Qualitative Approach. Jakarta: KBC.

Kasali, R. (2005). Manajemen Periklanan : Konsep dan Aplikasinya di Indonesia. Jakarta: Pusaka Grafiti.

Kotler, P., \& Armstrong. (2008). Dasar-dasar Pemasaran. (A. Sindoro, \& T. M. Plus, Trans.) Jakarta: PT. Indeks Gramedia.

Lestari, S. P. (2016). Hubungan Komunikasi Pemasaran dan Promosi dengan Keputusan Memilih Jasa Layanan Kesehatan (Studi pada Rumah Sakit Islam Lumajang). Majalah IImiah Inspiratif, 2(1).

Mairanda, \& Putra, P. (2015). Efektifitas Pengembangan Strategi Promotion Mix dalam Produk Tabungan Mudharabah Mutlaqah BNI Syariah Cabang Bekasi. Maslahah, 6(1).

Otoritas Jasa Keuangan. (2017). Statistik Perbankan Syariah . Jakarta: Departemen Perizinan dan Informasi Perbankan Deputi Direktur Publikasi dan Administrasi .

Putra, P. (2016). Analisis Faktor-Faktor yang Mempengaruhii Intensi Muzaki Membayar Zakat: Sebuah survey pada masyarakat Bekasi. Maslahah, 99-109.

Rosita, E. T. (2013, November 08). staff Marketing BMI Cabang Bekasi Timur. (Silviana, Interviewer)

Sari, Y., Sumarwan, U., \& Hosen, M. (2015). Analisis Faktor - Faktor Preferensi Etnis Tionghoa terhadap Bank Syariah di Indonesia. Al-Muzara'ah, 3(1).

Sugiyono. (2013). Metode Penelitian Kuantitatif, Kualitatif dan R\& D. Bandung: Alfabeta.

Suhendi, C. (2008). Kritik untuk Bank Syariah (Antara Harapan, Kenyataan dan Paradigma Rahmatan lil Alamin). Fokus Ekonomi, 7(1), 52-57.

Syibly, M. R. (2008). Mengkaji Kebutuhan Floating Market Muslim Terhadap Bank Syariah (Studi Kasus Anggota Pengajian Bisnis Al-Kautsar NU di Wilayah DIY). Millah, VII(1), 89-106.

Wadhan. (2011). Edukasi Marketing Bank Syariah. Al-Ihkam, VI(1), 91-106. 